\title{
LATIHAN SENAM TERHADAP KADAR GULA DARAH PADA PENDERITA DIABETES MELLITUS DI DESA PALUH BAJI KECAMATAN PANTAI LABU KABUPATEN DELI SERDANG
}

\section{Samuel Ginting ${ }^{1 *}$, Chaidir Saputra Harahap ${ }^{1}$, Grace Erlyn Damayanti Sitohang ${ }^{1}$, Pitriani $^{1}{ }^{1}$, Syatriawati ${ }^{1}$, Juni Mariati Simarmata ${ }^{1}$}

${ }^{1}$ Program Studi Ilmu Keperawatan , Institut Kesehatan Medistra Lubuk Pakam

\author{
Jln. Sudirman No.38 Lubuk Pakam, Kabupaten Deli Serdang, \\ Sumatera Utara - Indonesia \\ *email korespondensi author: sukaginting834@yahoo.co.id
}

DOI $10.35451 /$ jpk.v1i1.754

\begin{abstract}
Abstrak
Diabetes Melitus yang lebih sering dikenal dengan kencing manis adalah suatu penyakit atau kelainan yang mempengaruhi kemampuan tubuh dalam jumlah atau konsentrasi glukosa atau gula di dalam darah melebihi keadaan normal. Jenis pengabdain yang dilakukan pada bentuk quasi eksperiment (quasi experiment) menggunakan contoh rancangan time series design. Pengabdian ini bertujuan buat mengetahui dampak senam terhadap kadar gula darah dalam penderita diabetes mellitus pada Desa Paluh Baji Kecamatan Pantai Labu Kabupaten Deli Serdang Tahun 2012. Populasi dalam Pengabdian ini adalah seluruh penderita diabetes melitus di Desa Paluh Baji Kecamatan Pantai Labu Pekan Kabupaten Deli Serdang yaitu sebanyak 54 orang, dengan jumlah sampel sebanyak 35 orang. Teknik pengambilan sampel dilakukan dengan non probability dengan pendekatan teknik purposive sampling. Berdasarkan hasil uji statistik didapatkan nilai $p=0,012(a=0,05)$ maka dapat disimpulkan ada pengaruh yang signifikan antara Kadar Gula Darah sebelum dan sesudah dilakukan senam. Disarankan kepada penderita diabetes melitus agar dapat menerapkan senam dalam upaya penurunan kadar gula darah.
\end{abstract}

Kata Kunci : Senam, Kadar Gula Darah, Diabetes Melitus

\begin{abstract}
Diabetes mellitus was more commonly known as diabetes was a disease or disorder that affects the ability of the body in amounts or concentrations of glucose or sugar in the blood than normal WHO estimates the number of patients with diabetes mellitus have increased in the year 2030 as many as 12.0 million people. This type of research was a quasi-experiment (quasi experiment) with a model of design time series design. This study aims to determine the effect of exercise on blood sugar levels in people with diabetes mellitus in the Desa Paluh Baji Kecamatan Pantai Labu Kabupaten Deli Serdang 2012. The population in this study were all patients with diabetes mellitus in the Desa Paluh Baji Kecamatan Pantai Labu Kabupaten Deli Serdang week as many as 54 people, with a sample of as many as 35 people. Sampled technique with a non probability purposive sampling technique approach. Based on the results of statistical tests obtained $p$-value $=0.012(a=0.05)$ we can conclude there was significant influence between blood sugar levels before and after exercise. It was recommended to patients with diabetes mellitus in order to apply the exercises in an effort to decrease blood sugar levels.
\end{abstract}

Keywords : Gymnastics, Blood Sugar Levels, Diabetes Melitus 
Received: 17 June 2021 :: Accepted: 23 June 2021 :: Published: 30 June 2021

\section{Pendahuluan}

Pembangunan kesehatan adalah upaya yang dilaksanakan oleh semua komponen bangsa Bertujuan buat menaikkan kesadaran, kemauan \& kemampuan hayati sehat bagi setiap orang supaya terwujud derajat kesehatan masyarakat yang setinggitingginya. Indikator Kesehatan rakyat bisa dipandang menurut indikator nomor asa hidup, nomor kematian, nomor kesakitan dan status gizi rakyat (Husni, 2012).

Pengaruh globalisasi pada segala bidang, perkembangan teknologi dan industri sudah poly membawa perubahan dalam konduite dan gaya hayati rakyat dan situasi lingkungannya, contohnya perubahan pola konsumsi makanan, berkurangnya aktivitas fisik, dan meningkatnya pencemaran lingkungan. Seiring dengan meningkatnya jumlah penyakit tidak menular, perubahan ini tanpa disadari berkontribusi pada perubahan epidemiologi, seperti penyakit jantung koroner (PJK), kanker, diabetes (DM), dan hipertensi. Demikian pula, pola penyakit yang menyebabkan kematian juga menunjukkan perubahan epidemiologi, yaitu penyebab utama kematian telah bergeser dari penyakit menular menjadi penyakit tidak menular (degeneratif). Hasil Penyelidikan Kesehatan Dasar Tahun 2007 (Riskesdas) juga menunjukkan peningkatan yang signifikan pada kasus penyakit tidak menular, yang membuat Indonesia menghadapi beban ganda (Soegondo, 2007) Menurut Organisasi Kesehatan Dunia (2009), jumlah penderita diabetes adalah 7 juta. WHO memperkirakan bahwa jumlah penderita diabetes akan meningkat 12 juta pada tahun 2030. Indonesia merupakan urutan ke-4 penyadang penyakit Diabetes Mellitus setelah amerika serikat,china dan India. Hasil Riset Kesehatan Dasar (RISKESDAS) 2007, angka prevalensi Diabetes Mellitus tertinggi terdapat di provinsi Kalimantan dan Maluku utara (masing-masing $11,1 \%)$, dan diikuti Riau (10,4\%). Sedangkan prevalensi Diabetes Mellitus terendah ada di provinsi Papua $(1,7 \%)$, diikuti NTT (1,8\%). Berdasarkan prevalensi factor risiko Diabetes Mellitus seperti obesitas 19,1\%, perokok $(23,7 \%)$, kurang makan buah dan sayur $(93,6 \%)$, sering makan/minuman manis $(65,2 \%)$, kurang aktivitas Fisik $(48,2 \%)$, makanan yang berlemak $(12,8 \%)$, Gangguann mental emosional $(11,6 \%)$, dan konsumsi Alkohol (4,6\%) (Suyono, 2007).

Para ahli percaya bahwa latihan jasmani atau Latihan fisik merupakan salah satu prinsip dalam penatalaksanaan penyakit Diabetes Melitus. Kegiatan Aktivitas fisik harian dan latihan fisik secara teratur (3-4 kali seminggu selama sekitar 30 menit merupakan salah satu pilar dalam manajemen diabetes. Menurut Menke G. Frank pada Encyclopedia of Sport, sebagaimana Bannes and Company, New York, 1960, senam terdiri berdasarkan gerakan-gerakan yg luas/poly atau menyeluruh berdasarkan latihan-latihan yg bisa membangun atau membangun otot-otot tubuh seperti: pergelangan tangan, punggung, lengan dan sebagainya. Kelebihan dari gerakan senam yaitu mampu untuk membakar kalori tubuh sehingga bisa menurunkan kadar gula darah dan terjadi peningkatan genre darah yg bisa mengakibatkan lebih poly tersedia reseptor insulin dan reseptor tadi sebagai aktif (Rosyanelli, 2009). Berdasakan survei awal yg dilakukan sang peneliti diketahui bahwa di Desa Paluh Baji Kecamatan Pantai Labu Pekan Kabupaten Deli Serdang terdapat penderita Diabetes Mellitus sebanyak 56 orang selama tahun 2011, sedangkan pada 4 bulan terakhir pada tahun 2012 penderita Diabetes Mellitus yaitu sebanyak 54 orang. Di Desa Paluh Baji Kecamatan Pantai Labu Pekan Kabupaten Deli Serdang belum pernah dilakukan senam khusus untuk penderita diabetes mellitus sehingga banyak dari penderita diabetes mellitus yang tidak mengetahui cara mengontrol kadar gula darah.

\section{Metode}

Pengabdian ini dalam bentuk adalah eksperimental, desain Pengabdian quasi experiment (experiment semu) menggunakan 
Received: 17 June 2021 :: Accepted: 23 June 2021 :: Published: 30 June 2021

contoh rancangan time series design. yaitu sebelum dilaksanakannya perlakuan maka dilakukan observasi pada sample dan sesudah perlakuan juga dilakukan beberapa kali observasi (Sugiyono, 2008).

Teknik sampling yang digunakan non probability dengan pendekatan purposive sampling, yaitu Penentuan sampel menggunakan pertimbangan tertentu (Sugiono, 2008). Teknik ini digunakan oleh peneliti mengingat populasi pada Pengabdian ini yaitu penderita diabetes yang ada di Desa Paluh Baji Kecamatan Pantai Labu Pekan Kabupaten Deli Serdang ini adalah 54 orang, Untuk membatasi karakteristik dari sampel, dilakukan kriteria pemilihan yaitu kriteria inklusi dan kriteria eksklusi.

Pengukuran latihan gerak fisik dengan cara melihat kepada responden apakah dapat mengikuti gerakan senam dengan benar. Kemudian dikategorikan menjadi baik apabila responden dapat mengikuti lebih dari setengah gerakan senam yang dilakukan dan tidak baik apabila responden tidak dapat mengikuti gerakan senam yang dilakukan. Latihan gerak fisik dilakukan $2 \times$ seminggu (Pada hari kamis dan sabtu). Sebelum dan sesudah latihan gerak fisik dilakukan insfeksi Kadar Gula Darah (KGD).

Pengukuran dilakukan dengan pemeriksaan kadar gula darah. Sebelum senam maka kadar gula darah penderita diabetes diukur, kemudian setelah itu dilakukan senam selama 2 minggu sebanyak 4 kali, pada senam yang terakhir Maka kadar gula darah bisa diukur apakah terjadi penurunan kadar gula darah dalam pasien diabetes melitus

\section{Hasil dan Pembahasan}

Hasil Pengabdian ini dapat dilihat dari tabel di bawah ini,

1.Kadar Gula Darah Sebelum Dilakukan Senam di Desa Paluh Baji Kecamatan Pantai Labu Kabupaten Deli Serdang Tahun 2012.

Tabel 1 menunjukkan bahwa kadar gula darah sebelum dilakukan senam di Desa Paluh Baji Kecamatan Pantai Labu Kabupaten Deli Serdang
Tahun 2012 yaitu seluruh responden memiliki kadar gula darah $>120 \mathrm{mg} / \mathrm{dl}$ dan tidak ada responden yang memiliki kadar gula darah $<120 \mathrm{mg} / \mathrm{dl}$.

Tabel 1.Distribusi Kategori Penilaian Kadar Gula Darah Sebelum Dilakukan Senam di Desa Paluh Baji Kecamatan Pantai Labu Kabupaten Deli Serdang Tahun 2012

\begin{tabular}{cccc} 
No & Kategori & $\begin{array}{c}\text { Frekuensi } \\
\text { (Orang) }\end{array}$ & $\begin{array}{c}\text { Persentase } \\
(\%)\end{array}$ \\
\hline 1 & $\begin{array}{c}>120 \\
\mathrm{mg} / \mathrm{dl}\end{array}$ & 35 & 100,0 \\
2 & $\begin{array}{c}<120 \\
\mathrm{mg} / \mathrm{dl}\end{array}$ & 0 & 0 \\
\hline & Total & 35 & 100.0 \\
\hline
\end{tabular}

Masalah kesehatan yg terdapat waktu ini ditentukan sang gaya hidup, pola makan, faktor lingkungan kerja, olahraga dan stres. penyakit degeneratif, seperti penyakit jantung koroner (PJK), hipertensi, hiperlipidemia (peningkatan kadar lipid dalam darah), DM disebabkan oleh Perubahan gaya hidup terutama di kota-kota besar Namun, tampaknya tidak ada menjadi banyak data epidemiologi di Indonesia. Hal ini disebabkan Pengabdian epidemiologic sangat mahal biayanya (FKUI, 2009). Dari hasil distribusi frekuensi dapat dilihat bahwa kadar gula darah sebelum dilakukan senam di Desa Paluh Baji Kecamatan Pantai Labu Kabupaten Deli Serdang Tahun 2012 yaitu seluruh responden memiliki kadar gula darah $>120 \mathrm{mg} / \mathrm{dl}$ dan tidak ada responden yang memiliki kadar gula darah $<120 \mathrm{mg} / \mathrm{dl}$. Hal ini dapat diasumsikan bahwa sebelum melaksanakan senam maka kadar gula darah belum mengalami perubahan karena belum terjadi pembakaran gula dalam otot.

2.Kadar Gula Darah Sesudah Dilakukan Senam di Desa Paluh Baji Kecamatan Pantai Labu Kabupaten Deli Serdang Tahun 2012 
Received: 17 June 2021 :: Accepted: 23 June 2021 :: Published: 30 June 2021

Tabel 2 Distribusi Kategori Penilaian Kadar Gula Darah Sesudah Dilakukan Senam di Desa Paluh Baji Kecamatan Pantai Labu Kabupaten Deli Serdang Tahun 2012

\begin{tabular}{cccc} 
No & Kategori & $\begin{array}{c}\text { Frekuensi } \\
\text { (Orang) }\end{array}$ & $\begin{array}{c}\text { Persentase } \\
(\%)\end{array}$ \\
\hline 1 & $\begin{array}{c}<120 \\
\mathrm{mg} / \mathrm{dl} \\
>120\end{array}$ & 7 & 20,0 \\
2 & $\begin{array}{c}>120 \\
\mathrm{mg} / \mathrm{dl}\end{array}$ & 28 & 80,0 \\
\hline & Total & 35 & 100,0 \\
\hline
\end{tabular}

Tabel 2 di atas menunjukkan bahwa kadar gula darah sesudah dilakukan senam di Desa Paluh Baji Kecamatan Pantai Labu Kabupaten Deli Serdang Tahun 2012 yaitu responden yang memiliki kadar gula darah $<120$ $\mathrm{mg} / \mathrm{dl}$ sebanyak 28 orang $(80,0 \%)$ dan responden memiliki kadar gula darah $>120 \mathrm{mg} / \mathrm{dl}$ sebanyak 7 orang (20,0\%).

Berdasarkan spekulasi, gerakan senam diabetes merupakan gerakan yang cepat, namun tidak seintens senam bentuk (SKJ) tetapi juga tidak serendah pada senam lansia. yang terpenting gerakan senam diabetes itu sendiri sudah siap untuk membakar kalori tubuh sehingga dapat menurunkan kadar glukosa. Variasi gerakan pada senam diabetes sendiri cukup banyak sehingga senam diabetes dapat menggerakkan seluruh bagian tubuh dari ujung kepala sampai ujung kaki. Gerakan yang bervariasi dalam senam juga berfungsi sebagai media untuk melatih daya ingat di dalam otak, karena dengan membiasakan otak bekerja akan membantu meningkatkan daya ingat dan mencegah psikosis pikun (Husni, 2010). Karena berbagai manfaatnya,senam diabetes sebenarnya bukan hanya untuk penderita diabetes saja. Latihan Senam diabetes akan dapat dilakukan oleh orang yang bukan penderita diabetes, dengan tujuan untuk mencegah supaya bisa mencegah penyakit diabetes.
Hasil Pengabdian ini sejalan dengan Pengabdian yang dilakukan oleh Widyaningsih (2012) di RS Purbaratu Kota Tasikmalaya tentang tindakan senam yang membawa pengaruh dalam upaya penurunan kadar gula darah dalam pasien diabetes melitus, dari hasil didapat $70 \%$ pasien diabetes melitus mengalami penurunan kadar gula dalam darah dan $30 \%$ pasien diabetes melitus tidak mengalami penurunan kadar gula darah.

Para ahli percaya bahwa pengerahan tenaga atau latihan fisik adalah salah satu prinsip dalam pengelolaan DM, yaitu latihan kaki. Aktivitas fisik harian dan olahraga teratur (3-4 kali per minggu selama sekitar 30 menit) adalah salah satu pilar dalam manajemen diabetes. Olahraga yang dimaksud adalah jalan kaki, bersepeda santai, jogging, senam, dan renang. Latihan fisik ini usahakan diubah suaikan menggunakan umur dan status kesejukan jasmani.

\section{Kesimpulan}

Berdasarkan hasil uji statistik dan pembahasan tersebut diatas dapat disimpulkan bahwa pengaruh senam terhadap kadar gula darah pada penderita diabetes mellitus Di Desa Paluh Baji Kecamatan Pantai Labu Kabupaten Deli Serdang Tahun 2012, Seluruh responden memiliki kadar gula darah $>120 \mathrm{mg} / \mathrm{dl}$ sebelum dilakukan senam. Mayoritas responden memiliki kadar gula darah $<120 \mathrm{mg} / \mathrm{dl}$ yaitu sebanyak 28 orang $(80,0 \%)$ sesudah dilakukan senam. Ada pengaruh senam terhadap kadar gula darah pada penderita diabetes mellitus Di Desa Paluh Baji Kecamatan Pantai Labu Kabupaten Deli Serdang Tahun 2012. Berdasarkan hasil uji statistik dengan menggunakan uji dependen sample $t$ test/paired $t$ test menunjukan bahwa pValue yaitu 0.012 yang berarti $p$ Value $<$ dari 0.05 .

\section{Ucapan Terima Kasih}

Terimakasih Pengabdian ucapkan kepada seluruh pihak yang membantu Pengabdian ini. 
Received: 17 June 2021 :: Accepted: 23 June 2021 :: Published: 30 June 2021

\section{Daftar Pustaka}

Diabetes Melitus. Penerbit Kreasi Wacana, Bantul

Charles, 2010. Panduan latihan kebugaran fisik ( yang efektif dan aman). Lukman Offset, Yogyakarta

Depkes RI, 2006. Keputusan Menteri Kesehatan RI Nomor: 1216/MENKES/SK/XI/2001 tentang Pedoman Pengobatan Penyakit DM Edisi ke-4. Jakarta

Fitria, 2009. Diabetes. Penerbit Venus, Yogyakarta

FKUI, 2009. Pedoman Diet Diabetes Melitus. Penerbit Balai Pustaka FKUI, Jakarta

Husni, 2010. Pengaruh olah raga terhadap penurunan gula darah pasien DM jenis NIDDM di Poliklinik Penyakit Dalam RSUD Kabupaten Kudus. STIKES Ngudi Waluyo, Semarang

Mahendra, 2008. Insulin resistance versus insulin deficisncy in non insulin dependent diabetes mellitus problem and prospect. http://www.detikhealth.com. Diakses tanggal 15 April 2012.

Medicastore, 2010. Hubungan tingkat pengetahuan, sikap dan praktik (PSP) penderita diabetes mellitus mengenai pengelolaan diabetes mellitus dengan kendali kadar gula darah. Yogyakarta

Notoatmodjo S, 2010. I/mu perilaku kesehatan. Penerbit Rineka Cipta, Jakarta.

Riduan. 2009. Rumus dan Data dalam Analisis Statistika Edisi 3. Alfabeta, Bandung.

Sudartawan, 2008. Asuhan keperawatan diabetes mellitus. http://www.diabetesmelitus.com . Diakses pada tanggal 20 April 2012.

Setiadi. 2007. Konsep dan Penulisan Riset Keperawatan Edisi 1. Graha Ilmu, Yogyakarta.

Sjaifoellah, 2006. Buku ajar ilmu penyakit dalam.Jilid 1 Edisi 5. FKUI, Jakarta.
Soegondo, 2007. Diabetes Mellitus Penyakit Kencing Manis. Penerbit Kanisius, Yogyakarta .

Sugiyono. 2007. Metode Pengabdian Pendidikan. Alfabeta, Bandung.

Suyono, 2007. Modifikasi gaya hidup sehat cegah timbulnya penyakit DM . http://www.swaranet.com. Diunduh tanggal 10 April 2011.

Widianti, 2010.Senam Kesehatan. Nuha Medica, Yogyakarta. 